\title{
Az értés fél egészség
}

\section{Understanding is Half of the Success to Health}

\author{
Szerző: Borjádi Györgyi凹 \\ AIPM, Innovativ Gyógyszergyártók Egyesülete
}

Beküldve: 2016.08.30.

Kulcsszavak: egészségértés, egészségműveltség, egészségfejlesztés

Keywords: health literacy, health promotion

Az emberek egészségértési szintje szorosabb összefüggést mutat az egészségi állapotukkal, mint a jövedelmük, hogy van-e munkahelyük, vagy akár az iskolázottsági szintjük. Magyarországon sajnos minden második embernek korlátozott az egészségértése, ami a hazai kedvezőtlen egészségügyi mutatókban is nagy szerepet játszhat. Ezért döntött úgy az Innovatív Gyógyszergyártók Egyesülete (AIPM), hogy felkarolja az egészségértés problémáját és meghirdeti az első Egészségértés dijjat Magyarországon, Nekem Szól! címmel.

\section{MIT ÉRTÜNK EGÉSZSÉGÉRTÉS ALATT?}

Az egészségértés európai kutatásával foglalkozó fő szervezet, a Health Literacy Europe hálózat ${ }^{1} 2012$ ben megalkotta az egészségértés igen alapos és részletes definícióját:

„Az egészségértés azt jelenti, hogy az emberek mennyire képesek az életük különböző szakaszaiban az életminőségük fenntartása vagy javítása érdekében az egészségüggyel, betegségmegelőzéssel vagy egészségfejlesztéssel kapcsolatosan véleményt formálni és megfelelő döntéseket hozni, megvan-e az ehhez szükséges egészségügyi tudásszintjük, rendelkeznek-e a szükséges képességekkel, illetve mennyire motiváltak az egészségügyi információkhoz való hozzájutásban, ezek megértésében, értékelésében és alkalmazásában." ${ }^{2}$

Nehéz olyan magyar szót találni, amely pontosan kifejezi a health literacy szó jelentését. A szakemberek Magyarországon az egészségértés kifejezés mellett többek között használják az egészségmúveltség, egészségtudatosság, vagy akár az egészségjártasság kifejezést is. Ebben a cikkben egészségértésnek nevezzük az angol health literacy kifejezést.

\section{A MEGFELELő EGÉSZSÉGÉRTÉS ALAPVETŐEN MEGHATÁROZZA AZ EGÉSZSÉGET}

A jó egészségértés egyik alapvető előnye a megfelelő időben és helyen elvégzett szürés, melynek segítségével a korai stádiumban felismert betegség könnyebben kezelhető, gyógyítható. Ma már közhely, hogy a hatékony orvos-beteg kommunikáció milyen nagy jelentőségú a terápia során. Ha ez jól múködik, akkor a páciens a megfelelő helyre megy a kezelés során, vagyis nem „veszik el” a rendszerben. A megfelelően tájékozott betegnek más a hozzáállása, és ez jelentősen kihat a terápia hatékonyságára, végső soron a gyógyulásra. Csak az képes aktív szerepet játszani saját gyógyulásában, aki megérti és használja ezt a tudást, ezzel segíti az orvos munkáját és - ami a legfontosabb - ezáltal nagyobb eséllyel gyógyul meg. 
Amit tudunk:

1. Az emberek egészségértése a társadalom számára is előnyös. A megfelelő egészségértésű emberek aktívabban hozzá tudnak járulni a gazdasági fejlődéshez, magasabb a jövedelmük, tanultabbak, tájékozottabbak, nagyobb valószínúséggel vesznek részt a közösségi tevékenységekben és jobb egészségnek örvendenek.

2. Az alacsonyabb egészségértési szint jelentős hatással van az egyén egészségére. Akiknek nem megfelelő az egészségértése, kevésbé vesznek részt egészségfejlesztési-, vagy szűrőprogramokban, egészségtelenebbül élnek (magasabb köztük a dohányosok aránya), több a munkahelyi balesetük, rosszabbul kezelik a krónikus betegségeket (például: diabetes, HIV fertőzés vagy asztma), kevésbé tartják be a gyógyszerek használati útmutatójában foglaltakat, gyakrabban kerülnek kórházba, esetükben gyakoribb a korai halálozás.

3. A rossz egészségértés összefüggésben van a szociális helyzettel valamint az életkorral és tovább mélyítheti a létező különbségeket. Az alacsony egészségértésű embereknek általában alacsonyabb az iskolázottsági szintje, idősebbek, és szociális ellátásra szorulnak.

4. Az egészségértési képességek fejlesztése egy életen át tartó folyamat. Nincs olyan ember, akinek tökéletes lenne az egészségértése. Még a magasan képzett emberek számára is túl bonyolultnak tûnhetnek az egészségügyi rendszerek, különösen, ha az egészségi állapotuk miatt érzékenyebbek.

5. Az egészségértéssel összefüggő kompetenciák változóak a körülmények és a kulturális környezet függvényében. Az egészségértést egyéni és rendszerszintű tényezők befolyásolják. Ilyen például a kommunikációs képesség, az egészségügyi témák ismerete, a helyi egészségügy sajátosságai. Amikor ezek a rendszerek olyan tudást, vagy nyelvi képességeket igényelnek a használóiktól, melyeket túl nehéznek éreznek, akkor az negatív hatással lehet az egészségre.

6. Az alacsony egészségértés magasabb egészségügyi kiadásokkal jár. Az egészségértés nem megfelelő színvonala miatti egészségügyi kiadások a kanadai egészségügyi költségvetés 3-5\%-át tették ki 2009-ben. Az alacsony egészségértés az európai jóléti államok egészségügyi rendszereinek forrásait is jelentősen terhelik.

\section{Amit tehetünk:}

1. Az egészségértés holisztikus kormányzati és szociális megközelítése. Az egészségértés fejlesztése nem csak az egyén, a politikus, vagy az egészségügyi szakember felelőssége, hanem több szakma és ágazat együttműködésével valósulhat csak meg. Az egészségértés fejlesztését célzó programoknak a hétköznapokba kell illeszkedniük.

2. Egyszerű nyelvezetet használó kezdeményezések kifejlesztése. Az egyszerű nyelvezet azt jelenti, hogy a hallgató, vagy az olvasó első hallás vagy olvasás után megérti, amit hall vagy olvas. Például, az Egyesült Királyságban, Finnországban vagy Svédországban olyan kezdeményezések vagy szabályozók működnek, melyek célja, hogy a különböző hatóságok, intézmények a lakossággal való kommunikáció során egyszerü nyelvezetet használjanak.

3. A kutatásba és a mérésbe való befektetés. Fontos kutatásokat végezni az emberek egészségértési szintjéről, és arról, hogy a környezet menynyire támogatja az egészségértést. Elkészült az Európai Egészségértés Felmérés (European Health Literacy Survey³) nemzetközi kutatássorozat, melyhez 2015-ben Magyarország is csatlakozott, így aktuális hazai információink is vannak erről a területről. A kutatást érdemes lenne még több országra is kiterjeszteni és rendszeresen megismételni.

\section{HAZÁNKBAN MINDEN MÁSODIK EMBERNEK KORLÁTOZOTT AZ EGÉSZSÉGÉRTÉSE!}

Az Európai Egészségértés Felmérés (HLS-EU 47 kérdőív) célja az volt, hogy az egyes országokban felmérje, mennyire érzi az egyén könnyűnek vagy nehéznek a különböző egészségügyhöz köthető feladatok vagy szituációk megoldását, mint például:

- megérteni mit mond az orvos;

- eldönteni, hogy a tömegmédiumokból szerzett egészségügyi információ mennyire megbízható;

- információt találni arról, hogy mit tegyen olyan mentális problémák jelentkezésekor, mint a 
stressz vagy a depresszió;

- megérteni az élelmiszerek csomagolásán található információt;

- részt venni egészségfejlesztést célzó helyi tevékenységekben.

Az országonként 1000 fő bevonásával készült kutatásban első körben 8 ország vett részt: Ausztria, Németország, Görögország, Írország, Hollandia, Lengyelország, Spanyolország és Bulgária. 2015-ben a kutatás az Innovatív Gyógyszergyártók Egyesülete jóvoltából elkészült Magyarországon is, majd további európai országokban. A magyarországi eredményekből kiderült, hogy az egészségértési szint a magyar társadalom 20\%-ában elégtelen, 32\%-ában problémás, és csupán 49\%-ában elégséges, vagy kitűnő. Tehát hazánkban minden második emberek korlátozott az egészségértése! Számukra nehézséget jelenthet például annak eldöntése, hogy mikor, milyen betegség, panasz esetén kell háziorvoshoz, szakorvoshoz fordulni, vagy esetleg mentőt hívni, ezért magas számban vesznek igénybe nem megfelelő szintű ellátást. Mindez aránytalanul megterheli az egészségügyi ellátórendszert és indokolatlan párhuzamosságokat hoz létre. (A Szinapszis Kft. tudományos igénnyel megírt kutatási beszámolóját megtalálja a folyóirat e számában, illetve a részletes eredmények letölthetők a következő linken: www.aipm.hu/hu/egeszsegertes.)

\section{Egy követendő példa:}

Ausztriában, ahol az egészségértéssel szintén rendszerszintű problémák tapasztalhatók, 2012-ben az egészségpolitika 10 célkitűzése közé sorolták az egészségértés fejlesztését és 2015-ben megalakították az „Egészségértés Platformot”, melynek céljait a következőkben foglalták össze:

1. Elősegíteni az egészségértés javítását hosszú távon.

2. Elősegíteni a cél eléréséhez szükséges szervezetek és szereplők kapcsolatának kialakítását, a köztük való együttműködés platformjait, a hatékony tudáscserét és közös tanulást.

3. Kialakítani és koordinálni a politikai és társadalmi szereplők együttmúködését.

4. Létrehozni a közös tudást, megértést és innovációt.

5. Kialakítani egy monitoring rendszert, növelni az átláthatóságot és a minőséget. ${ }^{4}$
Érdemes lenne itthon is létrehozni egy hasonló platformot, hogy a különböző szakterületek összehangolják tevékenységeiket és az egészségértés fejlesztése mérhető módon, az együttmúködésre alapozva és egyfajta tervezett koncepció mentén haladjon.

\section{EGÉSZSÉGÉRTÉS DÍJ AZ EGÉSZSÉGÉRTÉS FEJ- LESZTÉSÉÉRT}

Az Innovatív Gyógyszergyártók Egyesülete (AIPM) fontosnak tartja az egészségértés magyarországi fejlesztését, ezért 2016. június 1-én meghirdette a „Nekem Szól! Egészségértés Díj 2016” című pályázatot, melynek fődíja 400.000 Ft. [1. ábra] A pályázat célja, hogy feltérképezze, és a közvéleménnyel megossza a legjobb egészségértést, egészségtudatosságot fejlesztő hazai programokat és gyakorlatokat. A pályázat során 4 kategóriában lehet beküldeni a nevezéseket. Olyan elkötelezett orvosok, újságírók, betegek, gyógyszerészek, ügynökségek, intézmények és egyéb szervezetek jelentkezését várjuk, akik valóban tesznek azért, hogy az emberek megértsék és hasznosítsák az egészségügyi információkat, így végső soron jobban kezükbe vegyék a sorsukat.

Pályázók köre:

Az Egészségértés Díjra pályázhat minden Magyarországon tartózkodó magánszemély, természetes és jogi személy, civil szervezet és állami szerv.

Pályázati kategóriák:

- Egészségügyi intézmények

Bármilyen egészségügyi intézmény (például, orvosi rendelő, gyógyszertár, kórház, egyéb rendelőintézet) által indított, az egészségértés javítását szolgáló projektek.

- Egészségügyi szakemberek Bármilyen egészségügyi szakember (háziorvos, szakorvos, gyógyszerész, szakápoló, védőnő, más egészségügyi végzettségű szakember) által indított, az egészségértés javítását szolgáló projektek.

- Betegszervezetek

Betegszervezetek által indított, az egészségértés javítását szolgáló projektek.

- Közvetlen lakossági kommunikáció 
Bármilyen, a lakosságot közvetlenül elérő, az egészségértést támogató kommunikáció (például, újságírók által írt cikkek, egészségügyi applikációk, pályázatok, versenyek, stb.)

\section{A zsűri tagjai:}

- dr. Pilling János, a zsúri elnöke (a SOTE Magatartástudományi Intézetének docense, az orvosi kommunikáció oktatás vezetője)

- Nógrádi Tóth Erzsébet (MúOSz Egészségügyi Szakosztály, elnök)

- Virányi Mariann (OGYÉl, főosztályvezető helyettes)

- Horváth-Sziklai Attila (Magyar Gyógyszerészi Kamara, hivatalvezető)

- dr. Pásztélyi Zsolt (MEDICINA 2000 - Poliklinikai és Járóbeteg Szakellátási Szövetség, leköszönő elnök)

- Torda Júlia (Kórházszövetség, kommunikációs vezető)

- Koltay Tünde (BEMOSZ, Betegszervezetek
Országos Szövetsége, elnök)

- Borjádi Györgyi (AIPM, Innovatív Gyógyszergyártók Egyesülete kommunikációs menedzser)

A pályázatra 2016. január 1. és 2016. október 14. között Magyarországon futó, egészségértést támogató projektek, kezdeményezések nevezhetők. A pályázati lapok és nevezési feltételek letölthetők a www.aipm.hu honlapról. A hiánytalanul kitöltött és aláirt pályázati lapot és a benyújtandó anyagokat elektronikus úton a nekemszol@vmkomm.hu címre kérjük elküldeni 2016. október 14. 24:00 óráig. Valamennyi érvényes pályázati anyagot szakértő zsűri bírálja el. A Nekem Szól! Egészségértés Díj 2016 eredményhirdetése 2016. november 11-én lesz, a nyertesek neveit közzétesszük a www.aipm.hu oldalon. A díj hivatalos átadására 2016. december 1én kerül majd sor.

A részletes pályázati kiírás, valamint további részletek megtalálhatóak a www.aipm.hu honlapon.

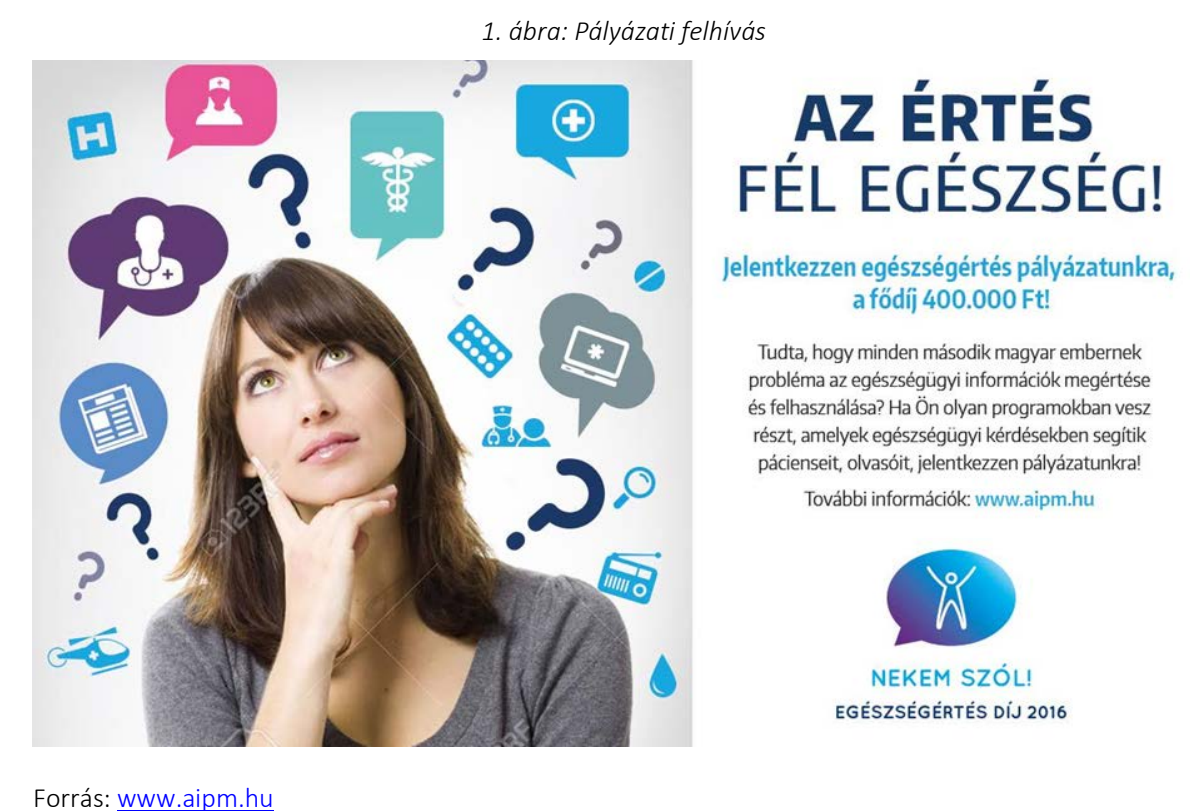

\footnotetext{
${ }^{1}$ Health Literacy Europe. http://www.healthliteracyeurope.net/ (Elérve: 2016.08.31.)

2 Health Literacy, the Solid Facts. (eds.) Kickbusch I, Pelikan JM, Apfel F, Tsouros AD. World Health Organization 2013

${ }^{3}$ HLS-EU Consortium (2012): Comparative Report of Health Literacy in Eight EU Member States. The European Health Literacy Survey HLS-EU (First Revised and Extended Version, Date July 5th, 2013), Online Publication: http://www.healthliteracy.eu (Elérve: 2016.08.31.)

"Pelikan J. Az egészségértés helyzete Magyarországon. „Nekem szól! egészségértés pályázatot bevezető konferencia”. Budapest, 2016. május 30.
} 